\title{
Culturally valuable minority crops provide a succession of floral resources for flower visitors in traditional orchard gardens
}

Olivia Norfolk*, Markus P. Eichhorn and Francis Gilbert

School of Life Sciences, University of Nottingham, University Park, Nottingham NG7 2RD, United Kingdom

*Corresponding author: Olivia Norfolk, University of Nottingham, University Park, Nottingham NG7 2RD, United Kingdom, plxon1@nottingham.ac.uk

\section{ABSTRACT}

Agricultural intensification typically has detrimental effects on pollinator communities, but diverse cropping systems that contain sequentially-flowering crops have the potential to benefit pollinators through the provision of additional floral resources. In this study we investigate the importance of cultivated flora for flower visitors in ten agricultural gardens in South Sinai, Egypt. Insect-flower interactions in gardens and unmanaged plots were surveyed across a four-month period in two environmentally distinct years (pre-flood and post-flood). Despite containing an equal abundance and diversity of wild plants as unmanaged habitat, gardens supported a higher abundance and diversity of flower visitors due to the additional presence of cultivated flora. Visitation networks exhibited dramatic intra-annual changes in composition, with cultivated plants becoming increasingly important in later months. Trends were highly conserved across two years despite highly contrasting rainfall. Several key crop species were strongly involved in shaping the structure of the networks, the majority of which were herbs with strong cultural significance (fennel, rosemary, mint) and grown incidentally alongside the primary orchard crops. Minority crops are frequently overlooked in agricultural systems due to their low economic value, but we 
show that they can have a dramatic influence upon the structure of visitation networks, increasing both pollinator abundance and diversity, and emphasising the link between cultural practices and biodiversity conservation.

\section{Key words}

diversification, homegarden, Egypt, pollination, sustainability

\section{Introduction}

Many agricultural pollination studies focus on the intensive agricultural systems that dominate temperate regions (Holzschuh et al. 2013; Le Féon et al. 2010;

Steffan-Dewenter \& Westphal 2008), but on a global scale $90 \%$ of all farms are less than two hectares in size (Tscharntke et al. 2012), with smallholder farms and homegardens making an essential contribution to food security in poorer regions (Horlings \& Marsden 2011). These small-scale agricultural systems typically serve just one household and are used primarily for subsistence crops, with cash crops sometimes grown to supplement household incomes They often employ the principles of diverse farming and habitually cultivate a range of crops that ripen in succession throughout the year (Fernandes \& Nair 1986; Jose \& Shanmugaratnam 1993). The presence of sequentially ripening and flowering crops is likely to influence and potentially increase the availability of floral resources for insect visitors across the entirety of their flight season.

In the hyper-arid mountains of South Sinai, the local Bedouin tribe cultivate agricultural gardens that can provide a wealth of floral resources for pollinators. In contrast to temperate systems, these actively irrigated gardens have been shown to 
support a higher diversity of wild plants than the unmanaged desert habitat (Norfolk et al 2013), with wild plants in the gardens receiving elevated levels of floral visitation (Norfolk \& Gilbert, 2014). Ornamental gardens have also been shown to enhance bee abundance in neighbouring Israel (Gotlieb, Hollender \& Mandelik 2011) and here we build upon these previous studies in order to determine the specific importance of crops for pollinators in this arid environment.

Smallholder farms in Africa and the Middle East tend to be heavily reliant on the economic returns from pollinator-dependent crops such as fruits and vegetables, and this leaves them particularly vulnerable in the face of pollinator declines (Gallia et al. 2009; Kasina et al. 2009). Despite the region's vulnerability, there is a marked geographical bias in the focus of pollination research, with the vast majority relating to temperate regions, in particular Europe and the USA (Archer et al. 2014; Mayer et al. 2011). The lack of research in poorer regions such as Northern Africa appears to be linked to a lack of funding opportunities and research infrastructure (Archer et al. 2014). Understanding the drivers of pollinator losses is important for tackling future food security and it is unfortunate that the most at-risk nations are those lacking the relevant research. This study aims to fill some of the knowledge gaps relating to smallholder agriculture and pollinators in this under-studied hyper-arid environment.

In this study we take a visitation network approach and quantify the insect-flower interactions within ten gardens across two four-month periods. We aim i) to evaluate the relative importance of cultivated and wild flora for insect flower visitors; ii) to assess whether the sequential flowering of crops influences the structure of visitation networks across the year; and iii) to determine which plant species are most integral to the structure of the visitation networks. We also compare the insect-flower interactions within the gardens to those found in unmanaged desert habitat to assess 
whether these additional cultivated flora have a positive impact upon flower-visitor abundance and diversity in the area. Our results demonstrate that these traditional agricultural gardens can supplement wild floral resources through the provision of sequentially-flowering crops.

\section{Methods}

\section{$2.1 \quad$ Study Site}

St Katherine $\left(28^{\circ} 33^{\prime} \mathrm{N}, 33^{\circ} 56^{\prime} \mathrm{E}\right)$ is the major non-coastal town in South Sinai, Egypt. (For a map of the study site, see Norfolk et al. 2013). It is a small modern township that began expanding in 1980 after the construction of a tarmac road, and now has a population of approximately 5000 (Gilbert 2011). It lies at an altitude of $1586 \mathrm{~m}$ a.s.I., at the heart the Ring Dyke, the highest mountain range in Egypt. The Sinai peninsula has a hyper-arid climate, experiencing extremely dry, hot summers and cold winters. Average annual rainfall ranges from $10 \mathrm{~mm}$ per year in low coastal areas to $50 \mathrm{~mm}$ per year in the high mountains, but this entire annual rainfall can fall within the space of a single day in the form of unpredictable flash floods (Cools et al. 2012). The local Bedouin traditionally farm orchard gardens in the surrounding mountains that depend on runoff rainwater from the floods to facilitate the growth of a variety of orchard products (such as almond, apricot, apple, pear and pomegranate) as well as vegetables and herbs (Norfolk et al. 2012; Zalat \& Gilbert 2008). This tradition continues in the town of St Katherine, where gardens are generally associated with permanent urban dwellings. Town gardens also utilise run-off rainwater, but rainfed well water irrigation is sometimes supplemented with imported water. The gardens are family owned and primarily used for subsistence, but also contain ornamental flowers and have been shown to provide important habitat for rare wild native plants 
(Norfolk et al. 2013). The gardens are managed traditionally, with pesticides and herbicides avoided; goats manure is used to fertilise soil. From satellite imaging we have estimated that there are between 500-600 gardens within the entire Ring Dyke region (Norfolk et al. 2013), with 36 within the town itself.

\subsection{Data collection}

Monthly surveys were carried out from April - July in 2012 and 2013 in ten gardens within the town of St Katherine. In 2013 we also surveyed six control plots in areas of unmanaged land within the town to give an indication of the plants and insects that would be present without active cultivation of the gardens. Average monthly daytime temperatures ranged from $22^{\circ} \mathrm{C}$ in April, $28^{\circ} \mathrm{C}$ in May, up to $32^{\circ} \mathrm{C}$ in June and July (RP5, 2013). No rain was recorded during the study period, but there were heavy floods at the beginning of 2013 , meaning water availability was higher in the second year (personal obs), leading us to classify 2012 as a pre-flood year and 2013 as a post-flood year.

The ten gardens were selected at random from the available pool of 36 gardens. The control plots of unmanaged land were chosen to typify the desert habitat of the area, with sandy soil and low-growing desert shrubs. The location of these control plots was determined by the availability of suitable sites within the town and was highly constrained by the density of gardens and buildings. See Figure 1 for a map of the study site. In each garden and control plot five $10 \times 10 \mathrm{~m}^{2}$ quadrats were measured out for repeat surveys across the season. Quadrats were placed contiguously, with the first quadrat randomly placed at a point along the garden wall and others towards the centre of the garden, giving a total survey area of $500 \mathrm{~m}^{2}$ per garden. Gardens 
ranged from $600-2800 \mathrm{~m}^{2}$ in size, so between $20-80 \%$ of each garden was surveyed.

Surveys were always carried out during sunny, non-windy days between 9am and 4pm. During sampling, a single collector thoroughly searched each $10 \times 10 \mathrm{~m}^{2}$ quadrat in turn, examining all flowering plants. All observed flower-visiting insects were net-collected directly from the plants, unless confident identification was possible in the field (honeybees and certain butterflies), and the identity of the plant species was recorded to establish the interaction. The collector walked at a steady pace around the quadrat searching each flowering plant once; if there were no visitors then the collector continued the walk and moved on to the next plant. When multiple visitors were observed simultaneously on one plant, the collector spent no more than five minutes (excluding handling time) catching insects from that particular plant.

Plants were identified in the field where possible or collected for identification using Boulos (1999-2005). Plants were classified as either wild or cultivated, with cultivated defined as any plant actively tended for consumption, household use or ornamental purposes. All captured insects were pinned and identified to species level for orders Hymenoptera and Lepidoptera and family Syrphidae by taxonomists. Coleoptera and non-syrphid Diptera were identified to family level and have been grouped into morphospecies based on visual characteristics to allow network analyses. Capture rates were $92 \%$ of observed insects; visitors that evaded capture were excluded from further analyses since species-level identification was not possible.

In 2013 we recorded floral abundance and floral species richness in the gardens and control plots. Floral abundance per garden or control plot was calculated as the total 
number of fresh flowers (i.e. petals and anthers intact and not dried) in the five quadrats. For plants with clustered, umbelled or spiked flower arrangements we counted the number of inflorescences rather than the number of single flowers; the average number of flowers per inflorescence was then calculated from three flower heads in the field, with floral abundance equal to the total number of inflorescences multiplied by the average number of flowers per inflorescence.

\subsection{Data analyses}

\section{Visitation networks}

In order to compute network statistics, visitation webs were created for each plot as quantitative interaction matrices with $\mathrm{n}$ rows (representing plant species) and $\mathrm{m}$ columns (representing insect species), with the value at the intersect representing the number of interactions observed between flower and insect. Monthly networks were constructed for each garden in both years (a total of 80 networks) and the control plots in 2013 (24 networks). Each garden network was then split into two networks, one containing only interactions with cultivated plants and the other containing only interactions with wild plants (a total of 160 networks).

Network level statistics were computed in R package bipartite (Dormann et al. 2009). Number of interactions, number of links and interaction diversity were computed for each network. Interaction diversity was defined as the exponential of the Shannon diversity of interactions (Dyer et al. 2010). All statistical analyses were performed with R.2.14.1 software (R Team, 2012).

We used linear mixed-effect models the R package Ime4 (Bates et al. 2011) to test for seasonal patterns in the abundance and diversity of cultivated and wild flora. 
Secondly we used the same models to test for a seasonal pattern in the number and diversity of flower-visitor interactions experienced by cultivated and wild plants. Models all included month and cultivated/wild as the fixed effects and garden $(\mathrm{N}=10)$ as a random effect to account for spatial variation. Response variables tested were a) floral abundance, b) floral species richness, c) number of interactions, d) number of links, and e) interaction diversity. The data from 2012 and 2013 were pooled for the cultivated/wild analyses, because although there were a higher number of interactions in the post-flood year (Imer: year; $X^{2}=77.1, d f=1, P=0.001$ ), there were no significant differences between the seasonal patterns in the two years for the mean number of interactions (month ${ }^{*}$ year; $X^{2}=2.88, d f=3, P=0.411$ ), number of links (month*year; $X^{2}=3.11, d f=3, P=0.375$ ) or interaction diversity (month*year; $X^{2}=1.10$, $d f=3, P=0.778)$. Number of interactions and number of links were count data so were fitted with a Poisson error distribution. Model fit was based upon AIC and followed Zuur et al. (2009), with the significance of fixed effects and their interactions tested by comparing models with a likelihood ratio test (distributed as Chi-squared)..

\section{Species similarity indices}

Species similarity of insects visiting wild and cultivated plants were compared using three complementary measures of beta diversity derived from $\mathrm{C}_{\mathrm{qN}}$ which together provide insight into the degree of overlap in rare, common and abundant flower visitors (Gotelli \& Chao 2013). As with Hill's numbers, $q$ is a parameter that determines the measure's sensitivity to species' relative abundances (Hill 1973) and $\mathrm{N}$ is the number of assemblages (in this case $\mathrm{N}=2$ ). $\mathrm{C}_{0 \mathrm{~N}}$ (the Sorenson similarity index) is an incidence-based index weighted towards rare species; $\mathrm{C}_{1 \mathrm{~N}}$ (the Horn overlap index) is an abundance-based similarity index weighted towards common species; and $\mathrm{C}_{2 \mathrm{~N}}$ (the Morisita-Horn similarity index) is an abundance-based 
similarity index weighted towards abundant species. $\mathrm{C}_{\mathrm{qN}}$ ranges between unity (when communities are identical) and zero (when communities are completely different). The three indices were calculated for cultivated and wild flower visitors (pooled from 2012 and 2013) in SPADE using 200 iterations (Chao \& Shen 2010).

\section{Topological importance}

We used topological importance as a way of determining the relative importance of cultivated and wild species and assessing their integration within the structure of the networks. We chose to use unweighted degree, one of the most direct measures of topological importance, because despite its relative simplicity it performs well when compared to other topological centrality measures (Pocock et al. 2011). We define topological importance (degree) as the total number of insect species that visited each plant species; a well-linked plant will have a higher topological importance and is likely to be a key species within the network. Degree and partner diversity were calculated for plants using specieslevel in the package bipartite (Dormann 2011) from cumulative networks of all ten gardens. Partner diversity was measured as the exponential Shannon diversity of the insect visitors.

The average a) topological importance and b) diversity of insect visitors were compared between wild and cultivated plants using linear-mixed-effects models with cultivated/wild as a fixed effect and month as a random effect. The model for topological importance was fitted with a Poisson error distribution and insect diversity with a normal error distribution. As with the previous models data from 2012 and 2013 were pooled.

Gardens and control plots 
Floral abundance, floral species richness and the three network statistics were compared between the 2013 gardens and unmanaged control plots. Plot type (garden or control) was included as a fixed effect, with the identity of each plot as a random effect. We were particularly interested in whether wild plants received more visits within the gardens or the control plots, so ran the above models with just wild species for comparison.

\section{Results}

\subsection{Characterisation of the insect-flower interactions within the gardens}

A total of 2298 insect-flower interactions were observed between 114 insect species and 59 plant species within the gardens over the course of the two years. Approximately three quarters of these interactions were with cultivated plants (1579 interactions) and one quarter with wild plants (621 interactions). Flower visitors interacted with 33 wild species and 26 cultivated plant species (Appendix A1), the most abundant of which were wild species Achillea santolina (17\% of all garden visits; present in eight of the ten gardens) and Chenopodium album (16\%; eight gardens); and cultivated species Beta vulgaris (14\%; seven gardens) and Foeniculum vulgare (10\%; eight gardens).

The most abundant visitors to cultivated plants belonged to the order Hymenoptera (34\%)(Table 1). Solitary bees were the most abundant group of Hymenoptera visiting cultivated plants (39\%), followed by solitary wasps (34\%) and managed honeybees (28\%). The most abundant visitors to wild species also belonged to the order Hymenoptera ( $41 \%)$. Of these, solitary bees were the most abundant group (68\%), followed by managed honeybees (17\%) and solitary wasps (12\%). 
Many of the most abundant insect species were observed visiting both cultivated and wild plant species (see Appendix 2 for species list), with managed honeybees a common visitor to both. These shared insect-visitors included generalist, cosmopolitan species with ranges spreading across Europe and Northern Africa such as Apis mellifera, Lampides boeticus (Long-tailed Blue butterfly) and hoverflies Eupeodes corollae and Syritta fasciata. Flowering crops also supported species with higher conservation importance, such as the leaf-cutter bee Megachile walkeri which is endemic to the Middle East, the colletid bee Hylaeus sinaitus which is endemic to Southern Sinai and Hylaeus sp A, a previously undescribed species (Dathe, pers. comm.). Despite some differences in the top ten species, the overall species similarity values were high between flower visitors utilising cultivated and wild species, with beta diversity values $\mathrm{C} q \mathrm{~N}$ of $0.812 \pm 0.03(q=0), 0.674 \pm 0.02(q=1)$ and $0.726 \pm 0.05(q=2)$. The incidence-based estimate $(q=0)$ was higher than the abundance-based estimates $(q=1,2)$, with rarer species showing a higher degree of overlap than common or abundant species.

\subsection{Seasonal changes in network structure and the importance of cultivated and wild flora}

Gardens contained a significantly higher floral abundance of cultivated plants than wild plants (Fig. $2 \mathrm{~A} ; \mathrm{X}^{2}=11.98, \mathrm{df}=1, \mathrm{P}<0.001$ ). Despite the higher abundances of cultivated flora, wild plants had the higher species richness (Fig. $2 B ; X^{2}=32.27, d f=1$, $P<0.001)$. Cultivated plants showed some increase in floral abundance across the year, but there was no seasonal interaction between the floral abundance of cultivated or wild plants (month ${ }^{*}$ cultivated/wild: $X^{2}=6.08, d f=3, P=0.108$ ). There was a strong seasonal interaction with the species richness of cultivated and wild flora; cultivated species richness stayed relatively constant in all four months, but wild 
plant species richness showed a steep decrease in June and July, reducing to half its initial level.

There were strong seasonal trends in the importance of cultivated and wild species within the visitation networks, with the same pattern observed in both two years, preflood and post-flood (Fig. 3). In April 2012 and 2013 approximately 50\% of interactions within the gardens involved wild plant species, but the proportion of interactions with wild plants decreased dramatically throughout the season and by July over $85 \%$ of interactions involved cultivated plants. Analysis of the network properties confirmed that these trends were highly significant (Table 2), with number of interactions (Fig 4 A), number of links (Fig 4 B) and interaction diversity (Fig 4 C) all increasing for cultivated plants and decreasing for wild plants in the later months.

\section{Topological importance}

Topological importance (total number of insect species that visited each plant species) was used to estimate the relative importance of wild and cultivated plants within the visitation networks. There was a clear turnover in the identity of the topologically important species across the season (Table 3) with several key cultivated species recurring in consecutive years; Eruca sativa (rocket) and Rosmarinus offinalis (rosemary) in April; Foeniculum vulgare (fennel) from May through to July; Origanum syriacum (oregano) and Medicago sativa (alfafa) in June; and Mentha longifolia shimperi (habak mint) and M. sativa (alfafa) in July.

Cultivated plants tended to have higher topological importance than wild species, with an average of $4.9( \pm 0.7)$ links to cultivated species and $3.2( \pm 0.4)$ to wild species $\left(X^{2}=30.2, d f=1, P<0.001\right)$. There was no significant difference between the Shannon diversity of insects visiting cultivated and wild species, with an average 
insect diversity of $0.89( \pm 0.09)$ associated with cultivated species and $0.70( \pm 0.08)$ with wild species $\left(X^{2}=2.59, d f=1, P=0.108\right)$.

\subsection{Gardens versus unmanaged plots}

In 2013 the gardens contained significantly higher floral abundances (Fig. $5 \mathrm{~A}$ ) and floral species richness (Fig. 5 B) than equal-sized plots of unmanaged land (abundance: $X^{2}=13.80, d f=1, P<0.001$, species richness: $X^{2}=14.31$, $d f=1, P<0.001$ ), with a significantly higher average number of insect-flower interactions $\left(X^{2}=19.68\right.$, $d f=1, P<0.001)$. When cultivated plants were not considered, there was no difference between wild plant floral abundance (Fig. $5 \mathrm{~A}$ ) or floral richness (Fig. $5 \mathrm{~B}$ ) (abundance: $X^{2}=0.57, d f=1, P=0.447$, species richness: $X^{2}=2.37, d f=1, P=0.123$ ). Observed interactions with wild plants were still significantly more numerous within the gardens (Fig. $5 \mathrm{C}: \mathrm{X}^{2}=4.73, \mathrm{df}=1, \mathrm{P}=0.030$ ), with a higher average number of links with insect species $\left(X^{2}=5.25, d f=1, P=0.022\right)$. There was no difference in the average wild plant interaction diversity in gardens and unmanaged plots $\left(X^{2}=3.38\right.$, $d f=1, P=0.066)$.

\section{Discussion}

\subsection{Floral and flower visitor communities within the gardens}

The agricultural gardens supported an abundant and diverse community of spontaneously occurring wild flora, with abundances matching those found in surrounding unmanaged habitat. Despite this, the majority of flower visitors were found utilising the crops, which provided a more abundant (though less diverse) floral community than the wild species. Wild flora has previously been shown to provide an important resource for flower visitors in the ground cover of apple orchards in Europe 
(Rosa García \& Miñarro 2014). We also found that plants growing beneath the orchard canopy are providing an important floral resource, but in our study system flowering vegetables and herbs are more significant for the pollinator community than wild flora.

As well as supporting many common pollinating species, such as honeybees and hoverflies, cultivated plants were also visited by a number of regionally endemic solitary bees, such as $M$. walkeri (Middle East) and $H$. sinaitus (Sinai). There was considerable overlap in the insect species visiting cultivated and wild flowers with beta diversity estimates confirming high similarity between the two communities. The incidence-based diversity estimate was higher than the abundance-based estimates, with rarer species showing a higher degree of overlap than common or abundant species. This implies that cultivated flora are not just visited by dominant generalist species, but provide resources for many of the rarer visitors that also visit wild species.

\subsection{Seasonal changes in the importance cultivated flora}

Analysing the temporal changes in the insect-flower interactions revealed dramatic seasonal patterns in importance of cultivated and wild flora within the visitation networks. In spring, wild plants played a large role within the networks, but in later months the majority of interactions were with cultivated flowers. This decline in wild plant interactions coincided with a decrease in wild flower species richness within the gardens. Pollinator abundance has been positively linked to floral species richness in other agro-ecosystems (Holzschuh et al. 2008; Kennedy et al. 2013) and it appears that cultivated plants provide an alternative source of nutrition for insects during the hotter and drier months of the year, when wild plant floral richness is low. 
The distinct temporal trend in the importance of cultivated plants was highly conserved across both years. Such a low level of inter-annual variation is particularly striking because heavy floods at the beginning of 2013 meant that water availability was considerably higher in the second year. There was a clear succession of key cultivated species, which played an integral role in network structuring across the four-month period. The same topologically important species occurred in both years and this may help to explain why the visitation networks exhibited such similar patterns despite the extreme environmental variation.

Seasonal planting typically provides households with year-round food security, but none of the topologically important plant species were food staples and all formed relatively minor parts of local peoples' diets such as salads and herbs. In fact many of the herbs that were deeply involved in the network structure (fennel, oregano, mint, rosemary) have a strong cultural significance and are widely consumed in Bedouin tea and used in traditional herbal medicines (Zalat \& Gilbert 2008). The link between cultural practices, traditional ecological knowledge and biodiversity conservation has been widely noted (Barthel et al. 2010; Ormsby \& Bhagwat 2010; Maffi 2005), and it is striking to think that a change in drinking preferences (from mint tea to instant coffee) could have serious consequences on pollination networks in this region. The inclusion of plants and flowers of cultural importance alongside food crops seems to have both social and ecological benefits that likely apply in other homegarden systems.

\subsection{Conservation potential of gardens in arid regions}

Agricultural gardens can boost flower-visitor abundances in heavily developed cities (Matteson et al. 2008), as can ornamental gardens in intensively managed 
farmlands (Samnegård et al. 2011); the Bedouin gardens seem to have a similar beneficial effect in a hyper-arid desert landscape, where particularly low nutrient levels and water availability limit floral abundances in the surrounding habitat. In our study, gardens contained more floral resources, with higher insect visitation, than plots of unmanaged land within the town. A high proportion of the flower visitors were pollinating species, such as solitary bees and hoverflies, many of which hold important conservation value in their own right. Cultivated plants provided an important resource for these flower visitors, but not at the expense of wild plants, which received more flower visitors inside gardens than they did outside.

Cultivated flowers became increasingly important later in the season (June and July), when temperatures can exceed $30^{\circ} \mathrm{C}$ (RP5 2013) and water becomes more scarce. Similar seasonal patterns have been observed with bee abundances in ornamental gardens in Israel (Gotlieb et al. 2011); in early spring, gardens and natural habitat contained equal bee abundance, but by June and July, numbers in the natural environment had declined and there was six-fold increase in bee abundance within the gardens. With global temperatures rising and rainfall becoming more erratic, we predict that such gardens will provide increasingly important habitat for desert species.

This study does not directly address the impact that the flower visitors have upon the eventual pollination success of crops or wild flora; however increased visitation by wild insects has been linked to increased fruit set in 41 crop systems worldwide (Garibaldi et al. 2013) and wild bees are known to improve fruit set in several crops that are found within the gardens, such as tomatoes (Greenleaf \& Kremen 2006), alfalfa (Cane 2002) and almond (Kennedy et al. 2013). Increased visitation rates to crops seem likely to bring agricultural benefits, but the high floral abundances found 
within the irrigated gardens could pose a risk to native flora if pollinators are attracted away from wild species. Previous research in the region has shown that the seed set of two species of native plants is not affected by the presence of the gardens, and that native plants within the gardens tended to be larger in size than those in the surrounding natural habitat (Norfolk and Gilbert 2014). This suggests that the gardens do not have a negative effect on the pollination success of wild flora, although further research to rule out dilution effects would be helpful.

\subsection{Conclusions}

Our results highlight the benefits of under-cropping within orchards and small-scale farms, demonstrating that cultivated flora can supplement wild floral resources and elongate the flowering season for pollinators. These traditional agricultural gardens enhanced the abundance and diversity of flower visitors above those in the unmanaged desert habitat, whilst maintaining the number of interactions with wild plant species. Minor crops with low economic but high cultural importance were the most utilized by flower visitors, and were strongly involved in shaping the structure of visitation networks, emphasising the positive link between cultural practices and biodiversity conservation.

\section{Acknowledgements}

We would like to thank The Leverhulme Trust (RPG256) for funding; our local guide N. Mansour for his invaluable help and support in the field; the staff and manager M. 
Qotb at the St Katherine Protectorate for permissions and assistance; the Egyptian Environmental Affairs Agency for permission to work in the Park; H. Mubarak and all the staff at Fox Camp for providing facilities; and our team of taxonomists who kindly donated their time and expertise, C. O'Toole (Apidae), M. Kuhlmann and H. Dathe (Colletidae), A. Pauly (Halictidae), C. Praz and A. Muller (Megachilidae), and C. Schmid-Egger (Sphecidae). Our research programme was set up in collaboration with Dr S. Zalat.

\section{References}

Archer CR, Pirk CWW, Carvalheiro LG, Nicolson, SW (2014) Economic and ecological implications of geographic bias in pollinator ecology in the light of pollinator declines. Oikos 123:401-407.

Barthel S, Folke C, Colding J (2010) Social-ecological memory in urban gardens-Retaining the capacity for management of ecosystem services. Global Environ Chang 20:255-265.

Bates D, Maechler M, Bolker B (2011) Ime4, Linear mixed-effects models using S4 classes. Published at http,//CRAN.R-project.org/package=Ime4.

Berkes F, Colding J, Folke C (2000) Rediscovery of traditional ecological knowledge as adaptive management. Ecol Appl 10:1251-1262.

Boulos L (2002) Flora of Egypt. Al Hadara Publishing, Cairo.

Calvet-Mir L, Gómez-Baggethun E, Reyes-García V (2012) Beyond food production: Ecosystem services provided by home gardens A case study in Vall Fosca, Catalan Pyrenees, Northeastern Spain. Ecol Econ 74:153-160.

Cane JH (2002) Pollinating Bees (Hymenoptera: Apiformes) of US Alfalfa Compared for Rates of Pod and Seed Set. J Econ Entomol 95:22-27.

Chao A, Shen TJ (2010) Program SPADE (Species Prediction and Diversity Estimation). Program and User's Guide. Published at http,//chao.stat.nthu.edu.tw. 
Cools J, Vanderkimpen P, El Afandi G, Abdelkhalek A, Fockedey S, El Sammany M, Abdallah G, EI Bihery M, Bauwens W, Huygens M (2012) An early warning system for flash floods in hyperarid Egypt. Nat Hazards Earth Syst Sci 12:443-457.

Dormann C (2011) How to be a specialist? Quantifying specialisation in pollination networks. Network Biol 1:1-20.

Dormann CF JF, Bluethgen N, Gruber B (2009) Indices, graphs and null models: analyzing bipartite ecological networks. Open Ecol J 2:7-24.

Dunne BM (2012) Saint Katherine's World Heritage Site, South Sinai: The conservation of the Bedouin high mountain orchard gardens and the roles of tourism and tradition. M.Sci Thesis. University College Dublin: Ireland.

Dyer LA, Walla TR, Greeney HF, Stireman lii JO, Hazen RF (2010) Diversity of Interactions: A Metric for Studies of Biodiversity. Biotropica 42:281-289.

Fernandes ECM, Nair PKR (1986) An evaluation of the structure and function of tropical homegardens. Agric Syst 21:279-310.

Gallai N, Salles JM, Settele J, Vaissière BE (2009) Economic valuation of the vulnerability of world agriculture confronted with pollinator decline. Ecol econ 68:810-821.

Garibaldi LA, Steffan-Dewenter I, Winfree R, Aizen MA, Bommarco R, Cunningham SA, Kremen C, Carvalheiro LG, Harder LD, Afik O (2013) Wild pollinators enhance fruit set of crops regardless of honey bee abundance. Science, 339:1608-1611.

Gilbert H (2011) 'This is Not Our Life, It's Just a Copy of Other People's': Bedu and the Price of 'Development' in South Sinai. Nomadic Peoples 15:7-32.

Gotelli NJ, Chao A (2013) Measuring and estimating species richness, species diversity, and biotic similarity from sampling data. pp. 195-211 in: Levin SA (ed.). Encyclopedia of Biodiversity, 2nd edition. Vol. 5. Academic Press, Waltham MA.

Gotlieb A, Hollender Y, Mandelik Y (2011) Gardening in the desert changes bee communities and pollination network characteristics. Basic Appl Ecol 12:310-320. 
Greenleaf SS, Kremen C (2006) Wild bee species increase tomato production and respond differently to surrounding land use in Northern California. Biol Conserv 133:81-87.

Hill MO (1973) Diversity and Evenness, A Unifying Notation and Its Consequences. Ecol 54:427-432. Holzschuh A, Dormann C, Tscharntke T, Steffan-Dewenter I (2013) Mass-flowering crops enhance wild bee abundance. Oecologia 172:477-484.

Holzschuh A, Steffan-Dewenter I, Tscharntke T (2008) Agricultural landscapes with organic crops support higher pollinator diversity. Oikos 117:354-361.

Horlings LG, Marsden TK (2011) Towards the real green revolution? Exploring the conceptual dimensions of a new ecological modernisation of agriculture that could 'feed the world'. Global Environ Chang 21:441-452.

Jha S, Kremen C (2013) Resource diversity and landscape-level homogeneity drive native bee foraging. PNAS 110:555-558.

Jha S, Vandermeer JH (2010) Impacts of coffee agroforestry management on tropical bee communities. Biol Conserv 143:1423-1431.

Jose D, Shanmugaratnam N (1993) Traditional homegardens of Kerala: a sustainable human ecosystem. Agroforestry Syst 24:203-213.

Kasina JM, Mburu J, Kraemer M, Holm-Mueller K (2009) Economic Benefit of Crop Pollination by Bees: A Case of Kakamega Small-Holder Farming in Western Kenya. Journal of Economic Entomology, 102:467-473.

Kennedy CM et al. (2013) A global quantitative synthesis of local and landscape effects on wild bee pollinators in agroecosystems. Ecol Lett 16:584-599.

Klein AM, Vaissière BE, Cane JH, Steffan-Dewenter I, Cunningham SA, Kremen C, Tscharntke T (2007) Importance of pollinators in changing landscapes for world crops. Proc Roy Soc B 274:303-313.

Kremen C (2002) Crop pollination from native bees at risk from agricultural intensification. PNAS 99:168121-6816. 
Kumar BM, Nair PKR (2004) The enigma of tropical homegardens In: Nair PKR, Rao MR, Buck LE (eds), New Vistas in Agroforestry Springer Netherlands, pp 135-152.

Le Féon V, Schermann-Legionnet A, Delettre Y, Aviron S, Billeter R, Bugter R, Hendrickx F, Burel F (2010) Intensification of agriculture, landscape composition and wild bee communities: A large scale study in four European countries. Agr Ecosyst Environ 137:143-150.

Maffi L (2005) Linguistic, Cultural, and Biological Diversity. Annu Rev Anthropol 34:599-617.

Matteson KC, Ascher JS, Langellotto GA (2008) Bee Richness and Abundance in New York City Urban Gardens. ESA 101:140-150.

Mayer C, Adler L, Armbruster S, Dafni A, Eardley C, Huang S, Kevan P, Ollerton J, Packer L, Ssymank A (2011) Pollination ecology in the 21st century: key questions for future research. J Poll Ecol 3:8-23.

Norfolk O, Abdel-Dayem M, Gilbert F (2012) Rainwater harvesting and arthropod biodiversity within an arid agro-ecosystem. Agr Ecosyst Environ 162:8-14.

Norfolk O, Eichhorn MP, Gilbert F (2013) Traditional agricultural gardens conserve wild plants and functional richness in arid South Sinai. Basic Appl Ecol 14:659-669.

Norfolk O, Gilbert F (2014) Insect visitation rates to wild flowers increase in the presence of arid agriculture in South Sinai, Egypt. J Arid Environ, in press.

Ormsby AA, Bhagwat SA (2010) Sacred forests of India: a strong tradition of community-based natural resource management. Environ Conserv 37:320-326.

Pocock MJO, Johnson O, Wasiuk D (2011) Succinctly assessing the topological importance of species in flower-pollinator networks. Ecol Complex 8:265-272.

Perevoltosky A (1981) Orchard Agriculture in the High Mountain Region of South Sinai. Human Ecol 9:331-357.

R Development Core Team (2010) R: A Language and Environment for Statistical Computing R Foundation for Statistical Computing, Vienna, Austria. 
Rosa García R, Miñarro M (2014) Role of floral resources in the conservation of pollinator communities in cider-apple orchards. Agr Ecosyst Environ 183:118-126.

RP5: Reliable Prognosis (2013) Weather in St Catherine (airport) http://rp5couk/Weather_in_St_Catherine_(airport) Accessed 09/09/2013.

Samnegård U, Persson AS, Smith HG (2011) Gardens benefit bees and enhance pollination in intensively managed farmland. Biol Conserv 144:2602 - 2606.

Steffan-Dewenter I, Westphal C (2008) The interplay of pollinator diversity, pollination services and landscape change. J Appl Ecol 45:737-741.

Tscharntke T, Clough Y, Wanger TC, Jackson L, Motzke I, Perfecto I, Vandermeer J, Whitbread A (2012) Global food security, biodiversity conservation and the future of agricultural intensification. Biol Conserv 151:53-59.

Viana BF, Boscolo D, Mariano Neto E, Lopes LE, Lopes AV, Ferreira PA, Pigozzo CM, Primo LM (2012) How well do we understand landscape effects on pollinators and pollination services? J Poll Ecol 7.

Williams NM, Kremen C (2007) Resource distributions among habitats determine solitary bee offspring production in a mosaic landscape. Ecol Appl 17:910-921.

Winfree R, Aguilar R, Vázquez DP, LeBuhn G, Aizen, MA (2009) A meta-analysis of bees' responses to anthropogenic disturbance. Ecol 90:2068-2076.

Zalat S, Gilbert F (2008) Gardens in a sacred landscape: Bedouin heritage and natural history in the high mountains of Sinai. American University in Cairo Press, Cairo.

Zuur A, leno EN, Walker N, Savelieve AA, Smith GM (2009) Mixed Effects Models and Extensions in Ecology with R. Springer. 
Table 1. Total number of interactions $(\mathrm{N})$ and total number of species $(\mathrm{S})$ observed from each arthropod order, with families included for important pollinating groups.

\begin{tabular}{|c|c|c|c|c|c|c|c|c|}
\hline & \multicolumn{4}{|c|}{ Cultivated flora } & \multicolumn{4}{|c|}{ Wild Flora } \\
\hline & \multicolumn{2}{|c|}{$\mathbf{N}$} & \multicolumn{2}{|c|}{ S } & \multicolumn{2}{|c|}{$\mathbf{N}$} & \multicolumn{2}{|c|}{ S } \\
\hline & 2012 & 2013 & 2012 & 2013 & 2012 & 2013 & 2012 & 2013 \\
\hline Hymenoptera & 214 & 347 & 42 & 47 & 166 & 163 & 30 & 23 \\
\hline Apidae & 77 & 106 & 10 & 5 & 95 & 93 & 8 & 7 \\
\hline Halictidae & 21 & 33 & 11 & 5 & 26 & 14 & 4 & 3 \\
\hline Colletidae & 67 & 60 & 2 & 3 & 11 & 8 & 3 & 2 \\
\hline Megachillidae & 20 & 23 & 5 & 4 & 25 & 23 & 9 & 3 \\
\hline Crabonidae & 24 & 123 & 10 & 28 & 8 & 25 & 6 & 8 \\
\hline Lepidoptera & 103 & 103 & 6 & 8 & 24 & 21 & 8 & 6 \\
\hline Lycaenidae & 100 & 96 & 3 & 4 & 19 & 15 & 5 & 4 \\
\hline Nymphalidae & 1 & & 1 & & & & & \\
\hline Pieridae & 2 & 7 & 2 & 4 & 3 & 6 & 3 & 2 \\
\hline Diptera & 248 & 339 & 27 & 22 & 85 & 81 & 19 & 17 \\
\hline Bombylidae & & & & & & 8 & & 5 \\
\hline Syrphidae & 138 & 300 & 8 & 10 & 66 & 65 & 8 & 5 \\
\hline Coleoptera & 45 & 172 & 8 & 9 & 24 & 52 & 11 & 8 \\
\hline Hemiptera & 4 & 11 & 3 & 1 & 4 & 1 & 1 & 1 \\
\hline Total: & 614 & 965 & 86 & 83 & 303 & 318 & 69 & 55 \\
\hline
\end{tabular}


Table 2. Seasonal variations in cultivated and wild plant interactions. Output from linear mixed effects models containing cultivated (cultivated or wild) and month as fixed effects and garden as a random factor.

\begin{tabular}{lcccc}
\hline \multirow{2}{*}{ Response variable } & \multirow{2}{*}{ Fixed effects } & \multicolumn{3}{c}{ Imer output } \\
\cline { 3 - 5 } & month*cultivated & 8.39 & 3 & $0.039^{*}$ \\
\hline Number of interactions & cultivated & 14.18 & 1 & $0.001^{* * *}$ \\
Number of links & month ${ }^{*}$ cultivated & 75.41 & 3 & $0.001^{* * *}$ \\
cultivated & 69.54 & 1 & $0.001^{* * *}$ \\
Interaction diversity & month*cultivated & 14.52 & 3 & $0.002^{* *}$ \\
& cultivated & 0.77 & 1 & 0.380 \\
\hline
\end{tabular}


Table 3. Seasonal trends in topologically important species, calculated from cumulative networks of all gardens. Plants with the highest topological importance are highlighted in bold. * indicates cultivated.

\begin{tabular}{|c|c|c|c|c|c|c|c|c|}
\hline & & \multicolumn{3}{|c|}{2012} & & \multicolumn{3}{|c|}{2013} \\
\hline & & $\begin{array}{l}\text { Topological } \\
\text { importance }\end{array}$ & $\begin{array}{l}\text { Partner } \\
\text { diversity }\end{array}$ & $\begin{array}{l}\% \text { of total } \\
\text { links }\end{array}$ & & $\begin{array}{l}\text { Topological } \\
\text { importance }\end{array}$ & $\begin{array}{l}\text { Partner } \\
\text { diversity }\end{array}$ & $\begin{array}{l}\% \text { of total } \\
\text { links }\end{array}$ \\
\hline \multirow[t]{5}{*}{ April } & ${ }^{*}$ Eruca sativa & 10 & 1.83 & 15 & ${ }^{\star}$ Eruca sativa & 8 & 1.55 & 13 \\
\hline & Caylusea hexagyna & 10 & 2.24 & 15 & ${ }^{\star}$ Salvia officinalis & 4 & 0.79 & 7 \\
\hline & ${ }^{*}$ Rosmarinus officinalis & 7 & 1.82 & 10 & ${ }^{\star}$ Rosmarinus officinalis & 4 & 1.39 & 7 \\
\hline & Arabidopsis kneuckeri & 7 & 1.11 & 10 & Zilla spinosa & 4 & 1.24 & 7 \\
\hline & Zilla spinosa & 4 & 0.79 & 6 & Alkanna orientalis & 4 & 1.08 & 7 \\
\hline \multirow[t]{5}{*}{ May } & ${ }^{\star}$ Foeniculum vulgare & 19 & 2.46 & 18 & ${ }^{\star}$ Foeniculum vulgare & 15 & 1.73 & 15 \\
\hline & ${ }^{*}$ Petroselinum crispum & 19 & 2.47 & 18 & Diplotaxis harra & 12 & 2.27 & 12 \\
\hline & Peganum harmala & 18 & 2.76 & 17 & Peganum harmala & 10 & 1.66 & 10 \\
\hline & ${ }^{*}$ Beta vulgaris & 13 & 2.41 & 13 & Zilla spinosa & 10 & 1.59 & 10 \\
\hline & ${ }^{*}$ Allium cepa & 6 & 1.75 & 6 & ${ }^{\star}$ Eruca sativa & 7 & 1.5 & 7 \\
\hline \multirow[t]{5}{*}{ June } & ${ }^{*}$ Foeniculum vulgare & 22 & 2.76 & 31 & ${ }^{\star}$ Foeniculum vulgare & 32 & 2.31 & 33 \\
\hline & ${ }^{*}$ Beta vulgaris & 11 & 1.7 & 16 & ${ }^{*}$ Allium cepa & 14 & 2.1 & 15 \\
\hline & ${ }^{*}$ Medicago sativa & 5 & 0.56 & 7 & ${ }^{\star}$ Origanum syriacum & 10 & 2.25 & 10 \\
\hline & Caylusea hexagyna & 5 & 1.61 & 7 & Ballota undulata & 7 & 1.48 & 7 \\
\hline & * Origanum syriacum & 4 & 1.15 & 6 & *Medicago sativa & 5 & 0.62 & 5 \\
\hline \multirow[t]{5}{*}{ July } & ${ }^{*}$ Foeniculum vulgare & 15 & 2.21 & 25 & ${ }^{\star}$ Foeniculum vulgare & 19 & 2.0 & 25 \\
\hline & Achillea fragrantissima & 14 & 2.27 & 23 & $\begin{array}{l}\text { *Mentha longifolia } \\
\text { schimperi }\end{array}$ & 16 & 2.43 & 21 \\
\hline & Ochradenus baccatus & 6 & 1.67 & 10 & Achillea santolina & 8 & 1.91 & 11 \\
\hline & ${ }^{*}$ Medicago sativa & 5 & 1.02 & 8 & ${ }^{*}$ Beta vulgaris & 5 & 1.3 & 7 \\
\hline & $\begin{array}{l}\text { * Mentha longifolia } \\
\text { schimperi }\end{array}$ & 5 & 1.56 & 8 & ${ }^{*}$ Medicago sativa & 4 & 1.28 & 5 \\
\hline
\end{tabular}


Figure 1. Map of study site in St Katherine Protectorate, South Sinai, with locations of gardens and unmanaged plots.

Figure 2. Mean (A) floral abundance, and (B) floral species richness, of cultivated and wild plants in the gardens across 2012 and 2013 ( \pm S.E.M).

Figure 3. Quantitative flower visitation networks for gardens across the sampling season, (A) pre-floods in 2012 and (B) post-floods in 2013. In each network the rectangles represent insect species (top row) and plant species (bottom row), and the connecting lines represent links between species. The width of the rectangle represents the total number of visits made, and the widths of the connecting lines represent the number of visits observed for that link. Links with cultivated plants are shown in grey and links with wild plants in black.

Figure 4. Network-level metrics for cultivated and wild plants within the gardens; mean number of $(A)$ interactions, $(B)$ links per network, and $(C)$ interaction diversity ( \pm S.E.M).

Figure 5. Comparison of (A) floral abundance, $(B)$ floral species richness, and (C) wild plant network statistics, in gardens versus unmanaged plots in 2013 . Values represent the mean per $500 \mathrm{~m}^{2}$ plot $( \pm$ S.E.M) across the year. 
Fig 1

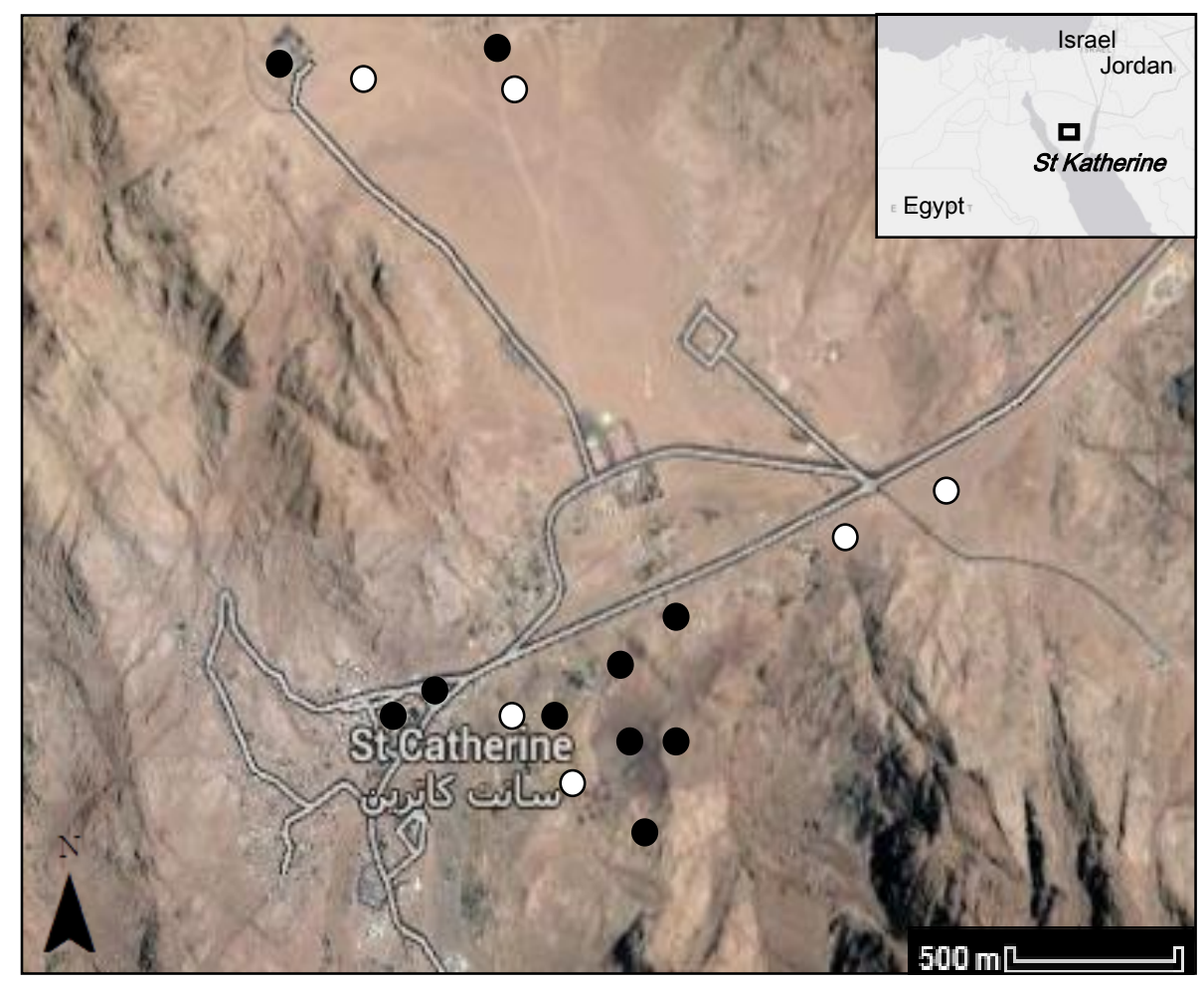

- Gardens

O Unmanaged plots 
FIG 2

A) $-\circ$ Cultivated $\quad-$-Wild
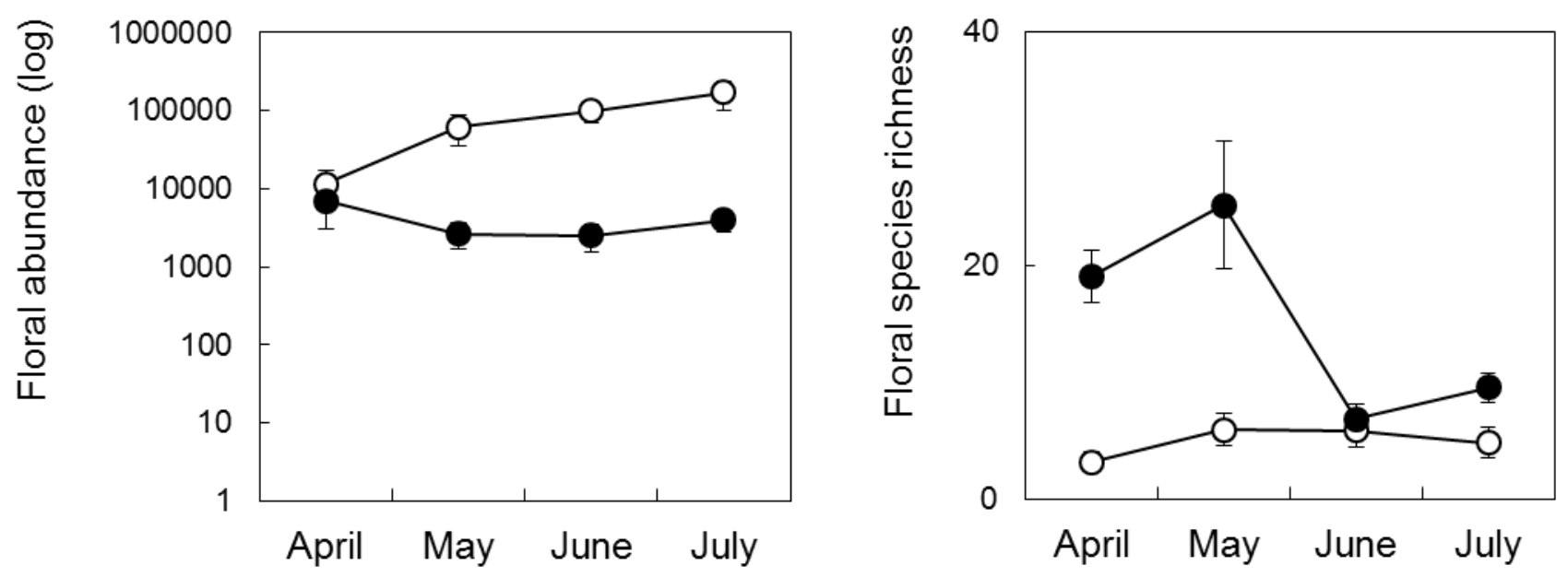
FIG 3

A) 2012 Pre-floods

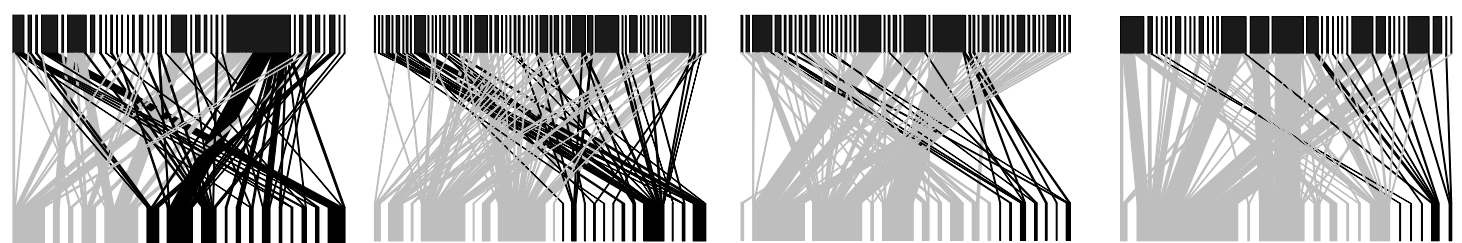

B) 2013 Post-floods

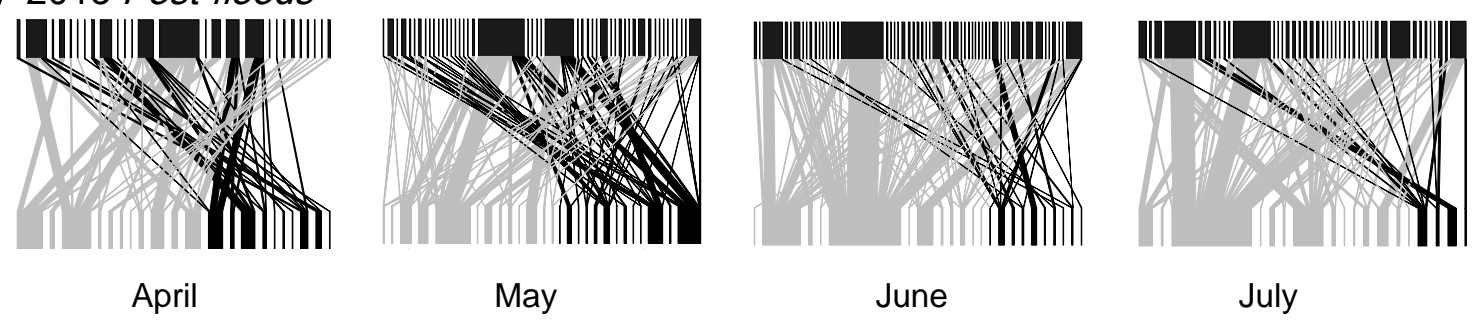


FIG 4

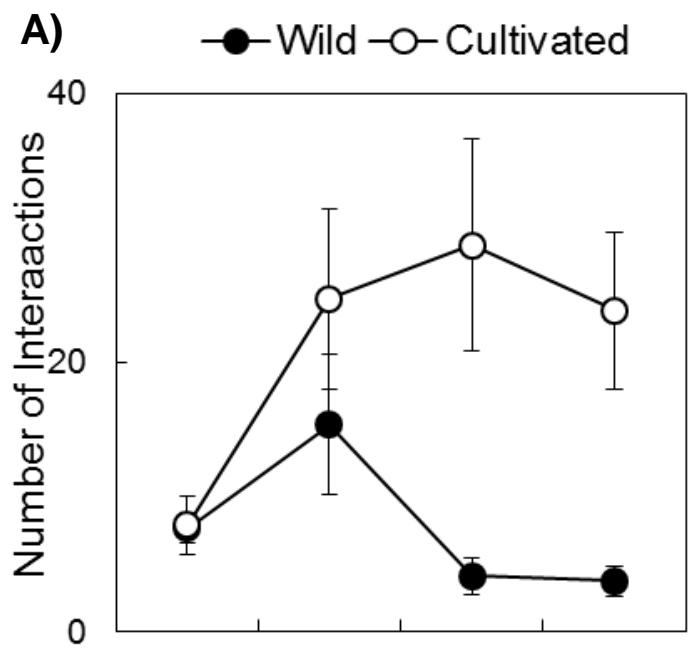

B)

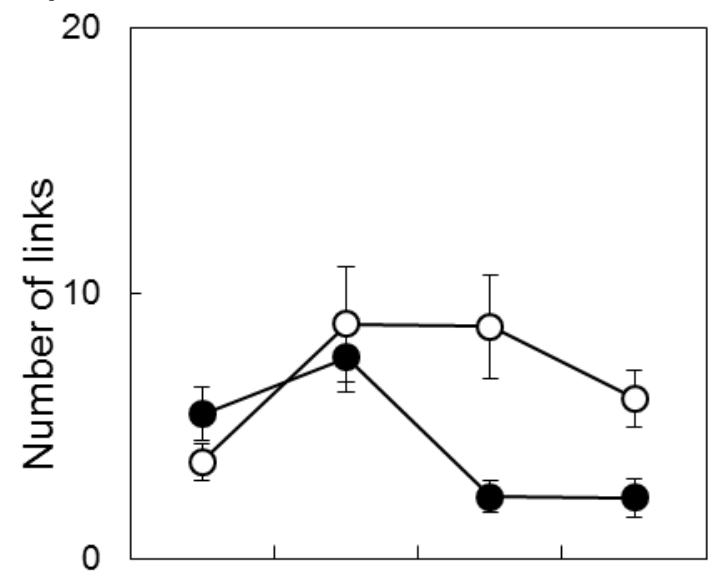

C)

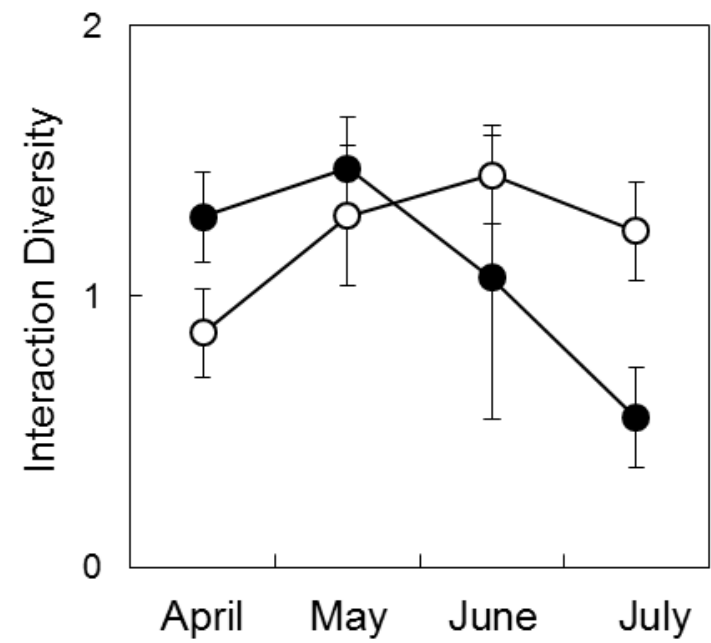


FIG 5

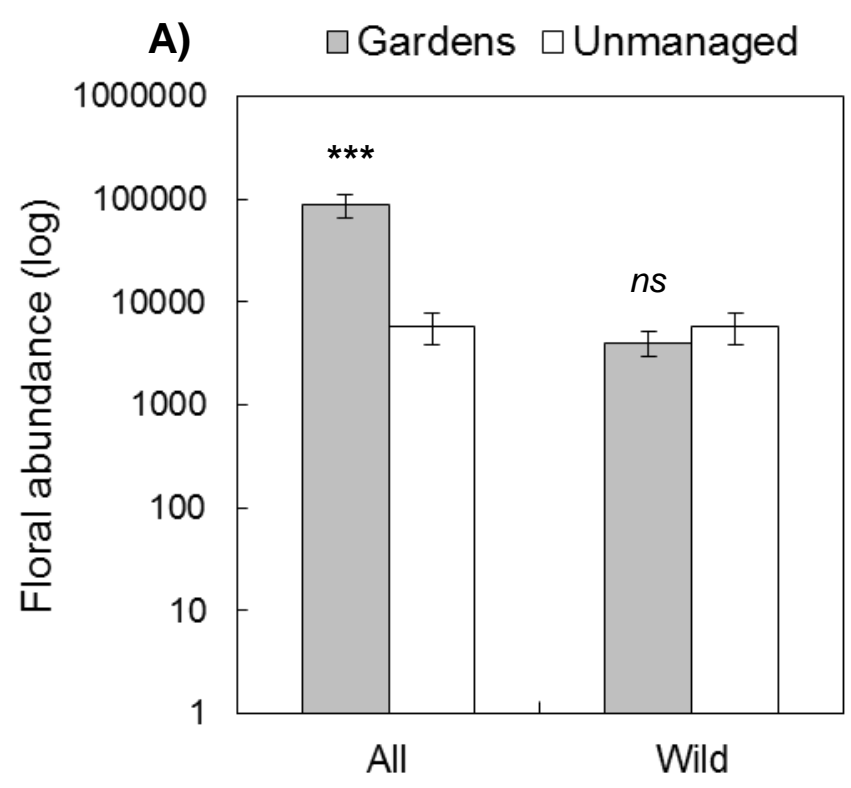

B)

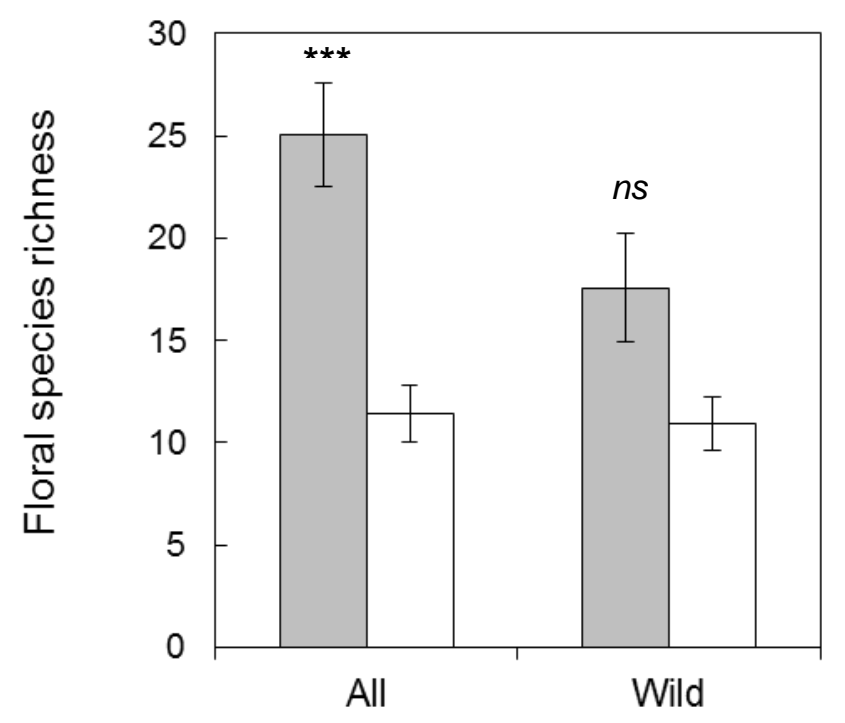

C)

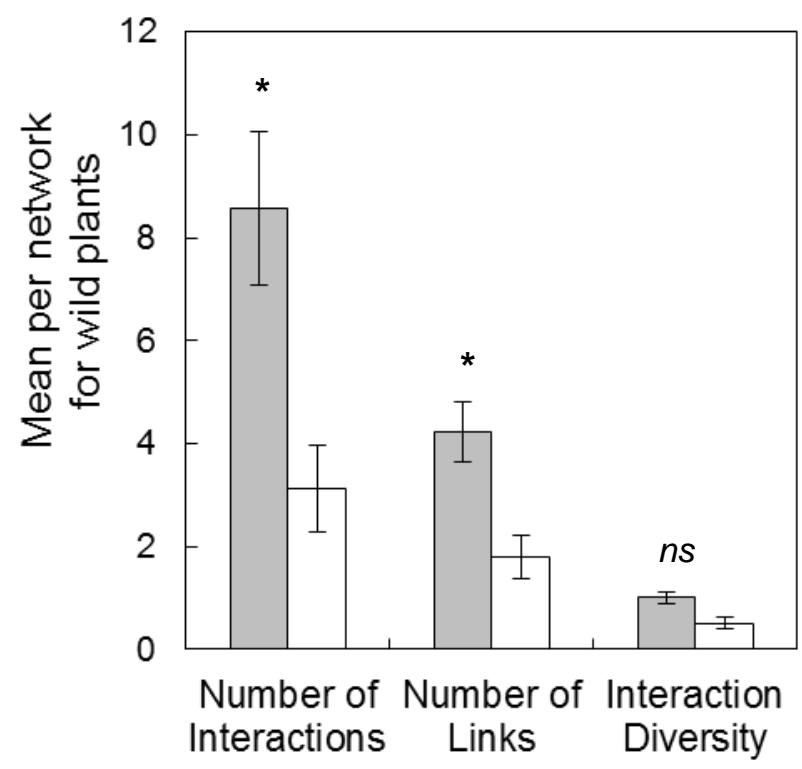


Appendix A1. Species list of the cultivated and wild flora that received insect visits.

\begin{tabular}{|c|c|c|c|c|c|c|c|}
\hline \multirow[b]{2}{*}{ Species } & \multirow[b]{2}{*}{ Family } & \multicolumn{2}{|c|}{ Visited in } & \multicolumn{4}{|c|}{ Number of flowers (2013) } \\
\hline & & 2012 & 2013 & Mean $^{\mathrm{a}}$ & \pm & S.E. & Cumulative $^{\mathrm{b}}$ \\
\hline \multicolumn{8}{|l|}{ CULTIVATED } \\
\hline \multirow{2}{*}{$\begin{array}{l}\text { Beta vulgaris } \mathrm{L} . \\
\text { Foeniculum } \\
\text { vulgare Mill. }\end{array}$} & Amaranthaceae & 1 & 1 & 1046.88 & \pm & 608.09 & 50250 \\
\hline & Apiaceae & 1 & 1 & 740.83 & \pm & 218.23 & 35560 \\
\hline Origanum syriacum L. & Lamiaceae & 1 & 1 & 325.00 & \pm & 173.40 & 15600 \\
\hline \multirow{3}{*}{$\begin{array}{l}\text { Olea europaea L. } \\
\text { Petroselinum crispum } \\
\text { (Mill.) Fuss } \\
\text { Mentha longifolia } \\
\text { schimperi (Briq.) Briq. }\end{array}$} & Oleaceae & 1 & 1 & 312.50 & \pm & 342.33 & 15000 \\
\hline & Apiaceae & 1 & 1 & 208.33 & \pm & 228.22 & 10000 \\
\hline & Lamiaceae & & 1 & 188.75 & \pm & 131.94 & 9060 \\
\hline Allium cepa L. & Amaranthaceae & 1 & 1 & 156.04 & \pm & 102.99 & 7490 \\
\hline Rosmarinus officinalis L. & Lamiaceae & 1 & 1 & 109.19 & \pm & 63.94 & 5241 \\
\hline Salvia officinalis L. & Lamiaceae & & 1 & 100.00 & \pm & 109.54 & 4800 \\
\hline Eruca sativa Mill. & Brassicaceae & 1 & 1 & 83.58 & \pm & 33.81 & 4012 \\
\hline Limonium sp. & Plumbaginaceae & 1 & 1 & 44.79 & \pm & 24.58 & 2150 \\
\hline Salvia multicaulis Vahl & Lamiaceae & & 1 & 32.25 & \pm & 15.03 & 1548 \\
\hline Medicago sativa $\mathrm{L}$. & Fabaceae & 1 & 1 & 28.88 & \pm & 10.88 & 1386 \\
\hline Mentha longifolia L. & Lamiaceae & 1 & 1 & 25.00 & \pm & 27.39 & 1200 \\
\hline Phaseolus vulgaris L. & Fabaceae & & 1 & 24.38 & \pm & 11.07 & 1170 \\
\hline Punica granatum L. & Lythraceae & 1 & 1 & 23.06 & \pm & 13.14 & 1107 \\
\hline Borago officinalis $\mathrm{L}$. & Boraginaceae & & 1 & 19.58 & \pm & 18.33 & 940 \\
\hline Mesembryanthemum sp. & Aizoaceae & 1 & 1 & 17.08 & \pm & 8.33 & 820 \\
\hline Portulaca oleracea L. & Portulaceae & 1 & 1 & 12.17 & \pm & 5.15 & 584 \\
\hline Alcea rosea $\mathrm{L}$. & Malvaceae & 1 & 1 & 8.44 & \pm & 3.76 & 405 \\
\hline Colutea istria Mill. & Fabaceae & 1 & 1 & 6.10 & \pm & 3.40 & 293 \\
\hline \multirow{2}{*}{$\begin{array}{l}\text { Rosa sp. } \\
\text { Solanum lycopersicum } \\
\text { L. }\end{array}$} & Rosaceae & & 1 & 4.17 & \pm & 3.19 & 200 \\
\hline & Solanaceae & & 1 & 2.75 & \pm & 2.23 & 132 \\
\hline Cucurbita pepo L. & Cucurbitaceae & 1 & 1 & 1.98 & \pm & 1.27 & 95 \\
\hline Nicotiana rustica L. & Solanaceae & & 1 & 1.06 & \pm & 0.88 & 51 \\
\hline \multicolumn{8}{|l|}{ WILD } \\
\hline Achillea santolina L. & Asteraceae & & 1 & 1256.25 & \pm & 577.66 & 60300 \\
\hline \multirow{4}{*}{$\begin{array}{l}\text { Chenopodium album L. } \\
\text { Caylusea hexagyna } \\
\text { (Forssk.) M.L.Green } \\
\text { Alkanna orientalis (L.) } \\
\text { Boiss } \\
\text { Ochradenus baccatus } \\
\text { Delile }\end{array}$} & Amaranthaceae & & 1 & 1200.00 & \pm & 929.45 & 57600 \\
\hline & Resedeaceae & 1 & 1 & 478.75 & \pm & 257.01 & 22980 \\
\hline & Boraginaceae & 1 & 1 & 96.94 & \pm & 41.65 & 4653 \\
\hline & Resedeaceae & 1 & 1 & 93.75 & \pm & 61.90 & 4500 \\
\hline Fagonia mollis Delile & Zygophyllaceae & 1 & 1 & 67.04 & \pm & 31.84 & 3218 \\
\hline Salvia sp. & Lamiaceae & 1 & & 66.67 & \pm & 51.09 & 3200 \\
\hline Artemisia judaica L. & Asteraceae & 1 & & 66.17 & \pm & 24.68 & 3176 \\
\hline Zilla spinosa (L.) Prantl & Brassicaceae & 1 & 1 & 58.77 & \pm & 33.03 & 2821 \\
\hline Peganum harmala L. & Nitrariaceae & 1 & 1 & 53.73 & \pm & 35.23 & 2579 \\
\hline
\end{tabular}




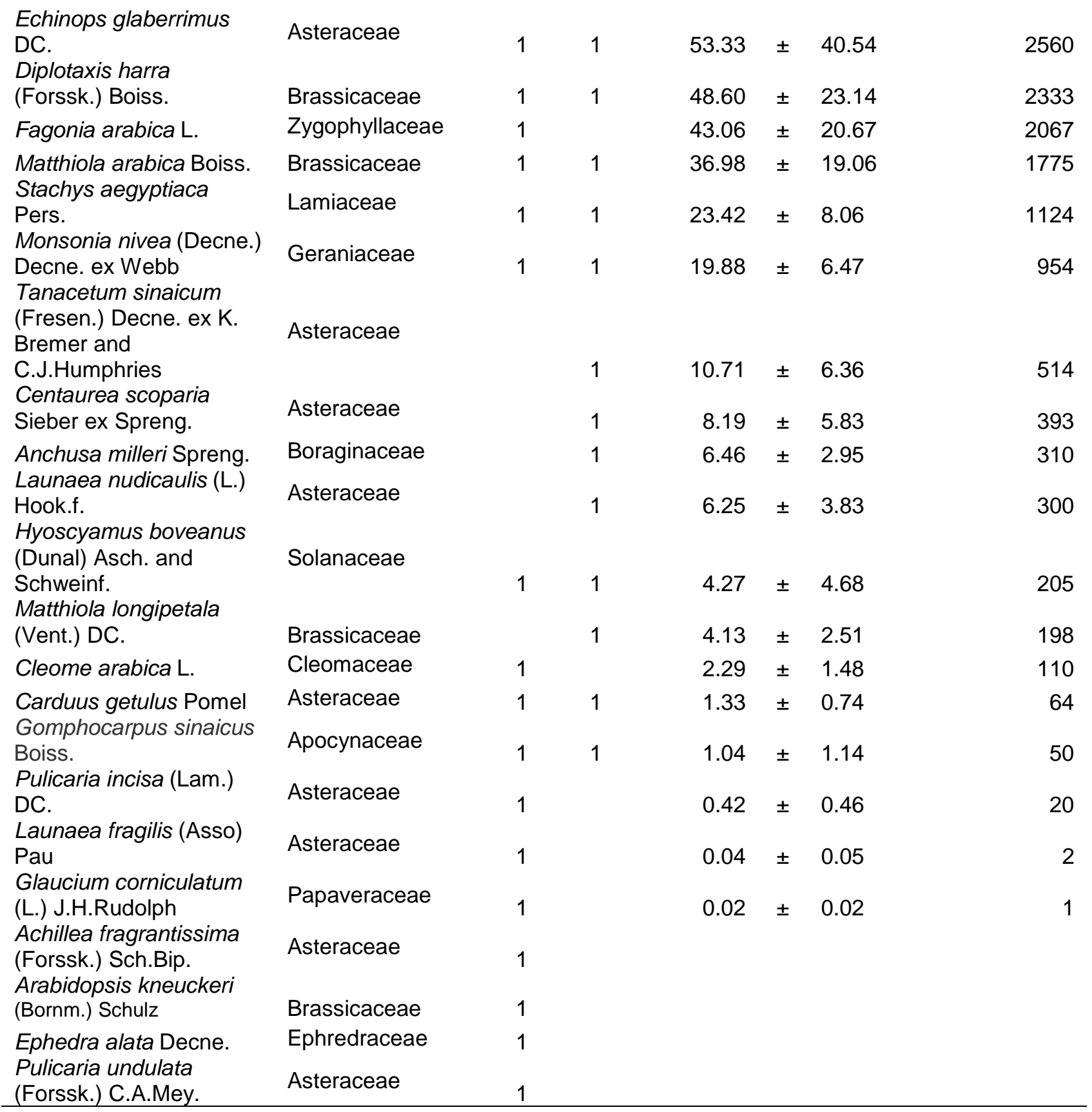

${ }^{a}$ Mean number of inflorescences per garden $\left(500 \mathrm{~m}^{2}\right)$ in 2013

${ }^{b}$ Cumulative number of inflorescences 
Appendix A2. Top ten most abundant insect species visiting cultivated and wild flowers.

\begin{tabular}{|c|c|c|c|c|c|c|c|c|c|c|c|}
\hline & & 2012 & & & & & & & 2013 & & \\
\hline Cultivated & $N$ & $\%$ & Wild & $N$ & $\%$ & Cultivated & $N$ & $\%$ & Wild & $N$ & $\%$ \\
\hline Apis mellifera $\mathrm{L}$. & 404 & 27 & E. corollae & 57 & 19 & S. fasciata & 268 & 28 & S. fasciata & 51 & 16 \\
\hline Lampides boeticus $\mathrm{L}$. & 164 & 11 & A. mellifera & 16 & 5 & L. boeticus & 92 & 9 & A. mellifera & 39 & 12 \\
\hline Syritta fasciata Wiedemann & & & & & & & & & Anthophora pauperata Walker & & \\
\hline 1830 & 83 & 6 & T. rosaceus & 14 & 5 & A. mellifera & 87 & 9 & 1871 & 39 & 12 \\
\hline Megachile (Eutricharaea) & & & & & & Coccinella septempunctata & & & Osmia laticella van der & & \\
\hline walkeri Dalla Torre 1896 & 75 & 5 & S. fasciata & 12 & 4 & L. & 69 & 7 & Zanden 1986 & 20 & 6 \\
\hline \multicolumn{12}{|l|}{ Hylaeus (Dentigera) sinaiticus } \\
\hline (Alfken 1938) & & & & & & & & & Tropinota sp. 1 & & \\
\hline & 61 & 4 & Attagenus sp A & 11 & 4 & Attagenus sp. A & 67 & 7 & & 18 & 5 \\
\hline \multicolumn{12}{|l|}{ Tarucus rosaceus (Austaut } \\
\hline \multirow{2}{*}{ 1885) } & & & F.Calliphoridae & & & Seladonia smaragdula & & & & & \\
\hline & 60 & 4 & Unknown sp. E & 11 & 4 & (Vachal 1895) & 50 & 5 & H. sinaiticus & 15 & 5 \\
\hline F.Chrysomelidae & & & Ischiodon aegyptius & & & & & & & & \\
\hline \multirow[t]{2}{*}{ Oulema sp. A } & & & (Wiedemann 1830) & & & & & & Coccinella septempunctata $L$. & & \\
\hline & 51 & 3 & & 9 & 3 & Oxybelus sp. A & 43 & 4 & 1758 & 12 & 4 \\
\hline Eupeodes corollae (Fabricius & & & L. boeticus & & & & & & & & \\
\hline 1794) & 39 & 3 & & 6 & 2 & Scolia carbonaria L. & 27 & 3 & E. corollae & 10 & 3 \\
\hline Leptotes pirithous $(\mathrm{L})$. & 38 & 3 & H. sinaiticus & 6 & 2 & Halictus tibialis Walker 1871 & 23 & 2 & H.tibialis & 10 & 3 \\
\hline F.Dermestidae & & & Sphaerophoria rueppellii & & & & & & & & \\
\hline Attagenus sp. A & 32 & 2 & Weidemann 1820 & 6 & 2 & Attagenus sp. B & 16 & 2 & Amegilla mucorea Klug 1844 & 9 & 3 \\
\hline
\end{tabular}


